\title{
Preparation of DNA/Gold Nanoparticle Encapsulated in Calcium Phosphate
}

\author{
Tomoko Ito, ${ }^{1}$ Koyuki Ibe, ${ }^{2}$ Tomohiro Uchino, ${ }^{1}$ Hiroyuki Ohshima, ${ }^{2}$ and Makoto Otsuka ${ }^{1}$ \\ ${ }^{1}$ Research Institute of Pharmaceutical Sciences, Musashino University, Shinmachi 1-1-20, Nishitokyo-Shi, Tokyo 202-8585, Japan \\ ${ }^{2}$ Graduate School of Pharmaceutical Sciences, Tokyo University of Science, 2641 Yamazaki, Noda-Shi, Chiba-Ken 278-8510, Japan \\ Correspondence should be addressed to Makoto Otsuka, motsuka@musashino-u.ac.jp
}

Received 27 October 2010; Revised 4 March 2011; Accepted 5 April 2011

Academic Editor: Guru V. Betageri

Copyright ( $) 2011$ Tomoko Ito et al. This is an open access article distributed under the Creative Commons Attribution License, which permits unrestricted use, distribution, and reproduction in any medium, provided the original work is properly cited.

Biocompatible DNA/gold nanoparticle complex with a protective calcium phosphate $(\mathrm{CaP})$ coating was prepared by incubating DNA/gold nanoparticle complex coated by hyaluronic acid in SBF (simulated body fluid) with a Ca concentration above 2 mM. The CaP-coated DNA complex was revealed to have high compatibility with cells and resistance against enzymatic degradation. By immersion in acetate buffer ( $\mathrm{pH} 4.5$ ), the CaP capsule released the contained DNA complex. This CaP capsule including a DNA complex is promising as a sustained-release system of DNA complexes for gene therapy.

\section{Introduction}

Gene therapy has been proposed as a novel strategy for the treatment of refractory disease. However, direct injection of naked DNA coding a therapeutic gene generally fails to exhibit a satisfactory therapeutic effect $[1,2]$. The low efficiency is due to the negative charge of the DNA molecules, which interferes with the binding of the complex to the cells. Too large DNA molecules also cause poor uptake by cells. DNase, which is present everywhere in the living body, seems to lower the efficiency of gene expression. Therefore, viral vectors have been widely used as carriers to deliver the therapeutic nucleic acids efficiently to the target cells. However, viral vectors have risks such as random recombination and immunogenicity [2]. Thus, safer alternative nonviral vectors such as polycations or cationic lipids have been explored as transfection mediators [2]. The DNA molecules can electrostatically associate with the cationic reagents and form small particles [3]. However, these DNA complexes are usually positively charged, which invites an adverse interaction with blood components or cells [4-6]. Moreover, the therapeutic effect is not satisfactory because of the short duration of gene expression [7].

Recently, drug delivery systems composed of inorganic nanoparticles, such as silica nanoparticles [8] or gold nanoparticles [9], have been developed. Gold nanoparticles have the advantages of easy preparation and the possibility of chemical modification on the surface [10]. They also have distinctive optical properties, showing strong surface plasmon bands from the visible region to the near-IR region depending on their shape $[11,12]$. Absorbed photoenergy is transformed to thermal energy, which stimulates drug release [13]. It should, thus, be possible to prepare an optically responsive DNA release system by binding DNA complexes to gold nanoparticles through thermodegradable bonds.

However, DNA/gold particle complexes are generally unstable in plasma because of their positive surface charge [14] and show nonspecific side effects with biocomponents as mentioned above. On the other hand, it is known that calcium-phosphate-based compounds, which have similar inorganic components to bone and teeth, are very biocompatible, and have been used as biomaterials, such as artificial bone or teeth [15]. In addition, they are dissolved and absorbed by the acid secreted from osteoclasts [16]. Such biocompatible and biodegradable materials are promising candidates as novel biocompatible and highly durable drugreleasing devices [17].

In this study, we developed novel DNA/gold nanoparticle complexes with protective calcium phosphate $(\mathrm{CaP})$ coating. The effects of the $\mathrm{CaP}$ coating on the protection against degradation by DNase and suppression of adverse interactions with cells were investigated. 


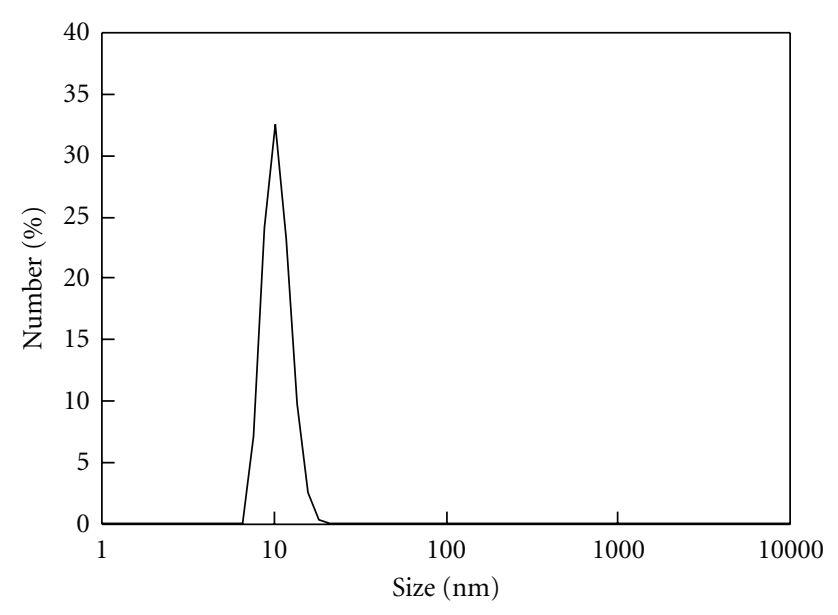

FIGURE 1: Size distribution profile of the gold nanoparticles.

\section{Materials and Methods}

2.1. Materials. Chloroauric acid $\left(\mathrm{HAuCl}_{4}\right)$, sodium borohydride $\left(\mathrm{NaBH}_{4}\right)$, and 2-aminoethanethiol were purchased from Wako Pure Chemical Industries, Ltd. Hyaluronic acid sodium salt (from a microorganism) and YOYO-1 iodide were obtained from Nacalai Tesque, Inc, and Invitrogen Corp, respectively. GFP-coding plasmid DNA (pDNA) with cytomegalovirus promoter was obtained from Clontech Laboratories, Inc. It was amplified in Escherichia coli and purified with a QIAGEN Plasmid Mega Kit.

2.2. Preparation of DNA/Gold (Au) Nanoparticle Complex. A solution of $0.01 \% \mathrm{HAuCl}_{4}(2 \mathrm{~mL})$ was reduced using $1 \mu \mathrm{L}$ of $0.38 \% \mathrm{NaBH}_{4}$ solution to produce Au nanoparticles. Five microliters of $330 \mu \mathrm{g} / \mathrm{mL}$ pDNA aqueous solution was mixed with aminoethanethiol (AET) solution $(5.6 \mathrm{mg} / \mathrm{mL}$, $0.5-8 \mu \mathrm{L}$; DNA : AET $=1: 1.8,3.6,7.2,14.4$, and $28.7(\mathrm{w} / \mathrm{w}))$. After $10 \mathrm{~min}, 60 \mu \mathrm{L}$ of Au suspension prepared as described above was added to the DNA/AET solution.

2.3. Preparation of DNA/Au Encapsulated by Calcium Phosphate. HA aqueous solution $(0.5 \mu \mathrm{L}-20 \mu \mathrm{L}, 4.8 \mathrm{mg} / \mathrm{mL})$ was added to $67 \mu \mathrm{L}$ of $\mathrm{pDNA} / \mathrm{AET} / \mathrm{Au}$ suspension (pDNA: AET $=1: 7.2(\mathrm{w} / \mathrm{w}))$. After stirring at room temperature for $30 \mathrm{~min}, 1.5$ times concentrated simulated body fluid (SBF) [18] was added to the pDNA/AET/Au/HA suspension at a ratio of $\mathrm{pDNA}: \mathrm{AET}: \mathrm{HA}=1: 7.2: 23.3(\mathrm{w} / \mathrm{w})$. The mixture was stirred at $37^{\circ} \mathrm{C}$ for $24 \mathrm{~h}$.

2.4. Electrophoresis. A suspension of $\mathrm{pDNA} / \mathrm{AET} / \mathrm{Au} / \mathrm{HA}$ with $1.5 \mathrm{SBF}$ was mixed with an equal volume of $30 \% \mathrm{NaCl}$ solution and incubated for 24 hours at $37^{\circ} \mathrm{C}$ to dissociate the DNA complex. The DNA complex was then diluted with pure water to adjust DNA concentration $([\mathrm{DNA}]=2 \mu \mathrm{g} / \mathrm{mL})$, and dissociation of DNA complex was evaluated by agarose gel electrophoresis $([$ agarose gel $]=1 \%)$.
2.5. Measurement of $\zeta$-Potential and Size. The sizes of Au nanoparticles and DNA/AET/Au/HA complex encapsulated in calcium phosphate were measured by a dynamic light scattering method (DLS) with a particle analyzer (Malvern Zetasizer Nano ZS). DNA/AET/Au complex or DNA/ $\mathrm{AET} / \mathrm{Au} / \mathrm{HA}$ complex suspension was diluted with water to $1 \mathrm{~mL}$, and $\zeta$-potential was measured using the same particle analyzer.

2.6. SEM-EDS Analysis. DNA/AET/Au/HA encapsulated by calcium phosphate was dropped onto adhesive carbon tape and vacuum-dried overnight. The surface was evaluated by SEM-EDS (JSM-7600F, JEOL Ltd., Japan) operated at $5 \mathrm{kV}$.

2.7. Cytotoxicity. Cytotoxicity of DNA/AET/Au/HA encapsulated by calcium phosphate was evaluated by WST-1 assay as follows: MLC-6 cells, an osteoclast-like cell line derived from a mouse, were seeded onto 24 -well plates at $9 \times 10^{3}$ cells per well and cultured for 2 days in McCoy $5 \mathrm{~A}$ media supplemented with $20 \%$ fetal bovine serum (FBS). The primary growth medium was then replaced with $500 \mu \mathrm{L}$ of fresh McCoy 5A with FBS. DNA/AET/Au/HA encapsulated by calcium phosphate was added to the cells $(1.65 \mu \mathrm{g}$ of plasmid per well). After incubation for 4 hours at $37^{\circ} \mathrm{C}$, $500 \mu \mathrm{L}$ of fresh medium was added to each well. After an additional $20 \mathrm{~h}$ of incubation at $37^{\circ} \mathrm{C}$, the cells were assayed with Premix WST-1 Cell Proliferation Assay System (Takara Bio Inc.).

2.8. Cellular Uptake of the Particles. Plasmid DNA was fluorescently labeled with YOYO-1 at a YOYO-1/nucleotide ratio of 0.1. DNA/AET/Au/HA complex was then made of the fluorescent DNA and mixed with $1.5 \mathrm{SBF}$ to be encapsulated by calcium phosphate (final $\mathrm{Ca}=2.6 \mathrm{mM}$ ). It was added to the cells $(1.65 \mu \mathrm{g}$ of plasmid per well). After incubation for 4 hours at $37^{\circ} \mathrm{C}, 500 \mu \mathrm{L}$ of fresh medium was added to each well. After an additional $20 \mathrm{~h}$ of incubation at $37^{\circ} \mathrm{C}$, the cells were observed by a fluorescence microscopy.

2.9. Enzymatic Degradation of DNA. The protective effect against the enzymatic degradation of DNA by encapsulation with calcium phosphate was evaluated using Hind III (Takara Bio Inc.) as follows: Hind III (0.5 unit) was added to the DNA/AET/Au/HA encapsulated by calcium phosphate suspension ( $\mathrm{DNA}=190 \mathrm{ng}$ ) in accordance with the instructions for the reagent. The degradation of DNA was evaluated by agarose gel electrophoresis ([agarose gel $]=1 \%$ ).

2.10. Statistical Analysis. Significant differences between two independent groups were examined by Student's $t$-test. Oneway analysis of variance (ANOVA) was used to determine significant differences among six groups.

\section{Results and Discussion}

3.1. Formation of DNA/AET/Au/HA Complex Encapsulated in Calcium Phosphate. Small gold nanoparticles were readily 


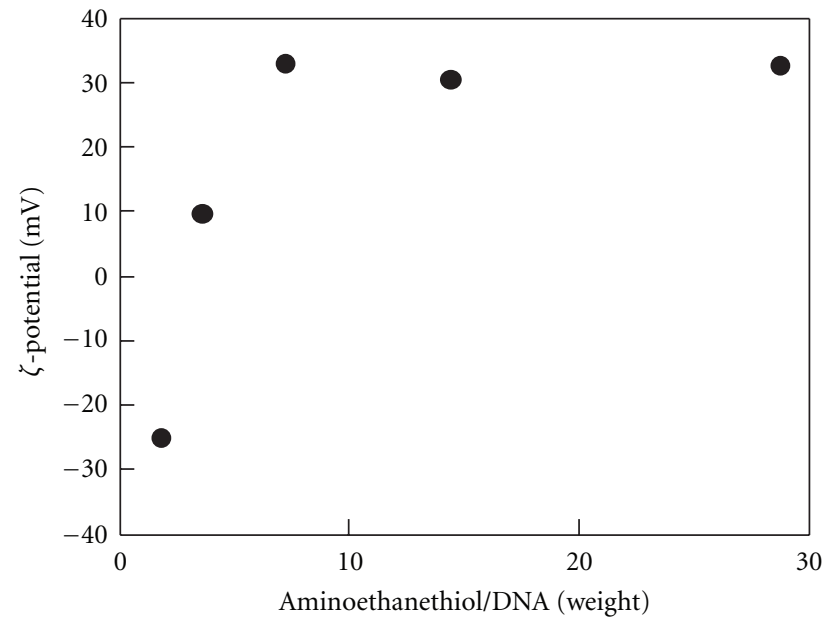

(a)

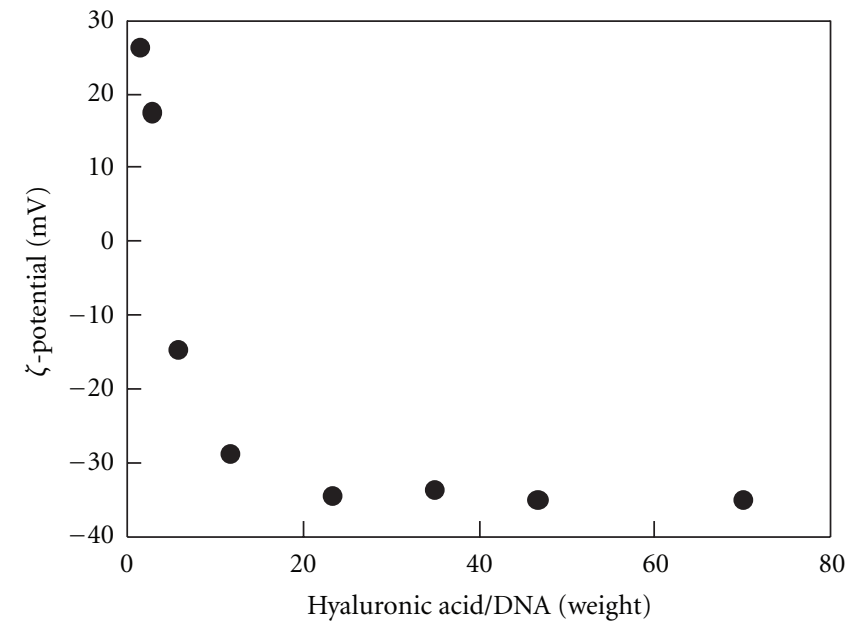

(b)

FIgURE 2: $\zeta$-potential of the complex particles composed of (a) DNA, AET, and Au; (b) DNA, AET, Au, and HA.

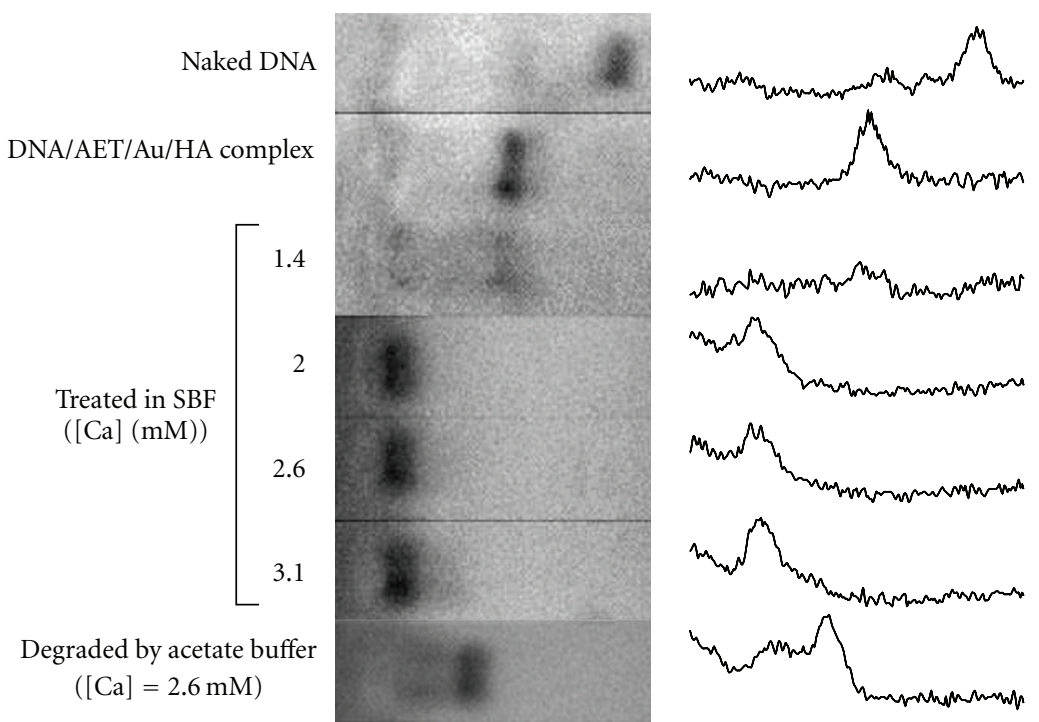

FIgURE 3: Agarose gel electrophoresis profile of the DNA complexes treated in SBF with various Ca concentrations. Complexes were electrophoresed after dissociation in $15 \% \mathrm{NaCl}$. The lowest line represents the result with a DNA complex treated in SBF with $[\mathrm{Ca}]=$ $2.6 \mathrm{mM}$ and degraded in an acetate buffer.

obtained by reduction of $\mathrm{HAuCl}_{4}$ by $\mathrm{NaBH}_{4}$. As shown in Figure 1, gold nanoparticles have a relatively narrow distribution in size with PdI $=0.834$. Their number-average size was $10.5 \mathrm{~nm}$ with the standard deviation of $1.90 \mathrm{~nm}$. It is known that thiol groups bind to gold nanoparticles [10]. AET was added to positively charge the gold nanoparticle surface. To decide on a suitable ratio of AET to DNA, various volumes of AET solution were premixed with DNA solution and then added to Au suspension. With increasing AET/DNA ratio, $\zeta$-potential of the DNA/AET/Au complex increased and was saturated at $33 \mathrm{mV}$ at AET/DNA $=7.2$ (in weight) (Figure 2(a)). This ratio, where the highest potential was obtained with the minimal amount of AET, was employed in the following experiments.
DNA/AET/Au complex was then encapsulated in a $\mathrm{CaP}$ membrane using SBF. An SBF has a similar inorganic ion concentration to that of human blood plasma and is supersaturated against hydroxyapatite (Ca ion $=2.5 \mathrm{mM})$. In this study, 1.5 times concentrated SBF (Ca ion $=3.8 \mathrm{mM}$, $\mathrm{pH}$ 7.25) was used to deposit apatite onto the DNA/gold complex surfaces. An apatite layer is known to be formed on bioactive materials with phosphoric acid or carboxylic acid groups [19]. Hyaluronic acid (HA) was then added to coat the $\mathrm{pDNA} / \mathrm{AET} / \mathrm{Au}$ complex suspension to facilitate the deposition of calcium phosphate on the complex.

Various amounts of HA were added to DNA/AET/Au complex (DNA:AET $=1: 7.2$ in weight), and $\zeta$-potential 


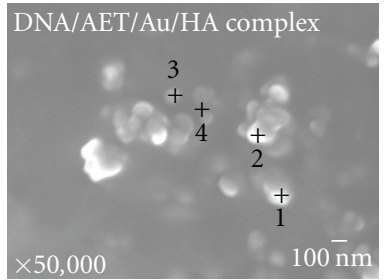

\begin{tabular}{|c|c|c|c|c|c|c|c|c|c|c|c|}
\hline & $\mathrm{C}$ & $\mathrm{O}$ & $\mathrm{Na}$ & $\mathrm{Mg}$ & $\mathrm{P}$ & $\mathrm{S}$ & $\mathrm{Cl}$ & $\mathrm{K}$ & $\mathrm{Ca}$ & $\mathrm{Au}$ & $\begin{array}{c}\text { Total } \\
(\mathrm{mol} \%)\end{array}$ \\
\hline 1 & 95.3 & 1.3 & 0 & 0 & 0.2 & 0.2 & 2.6 & 0 & 0 & 0.4 & 100 \\
\hline 2 & 96.1 & 2.6 & 0.2 & 0 & 0.5 & 0 & 0 & 0 & 0 & 0.6 & 100 \\
\hline 3 & 97.5 & 1.9 & 0 & 0 & 0.5 & 0 & 0 & 0 & 0 & 0.2 & 100 \\
\hline 4 & 97.4 & 2.3 & 0 & 0 & 0.1 & 0.1 & 0 & 0 & 0 & 0 & 100 \\
\hline
\end{tabular}

(a)

Figure 4: SEM-EDS analysis of (a) DNA/AET/Au/HA complex; (prepared in SBF with $[\mathrm{Ca}]=2.6 \mathrm{mM}$ ).

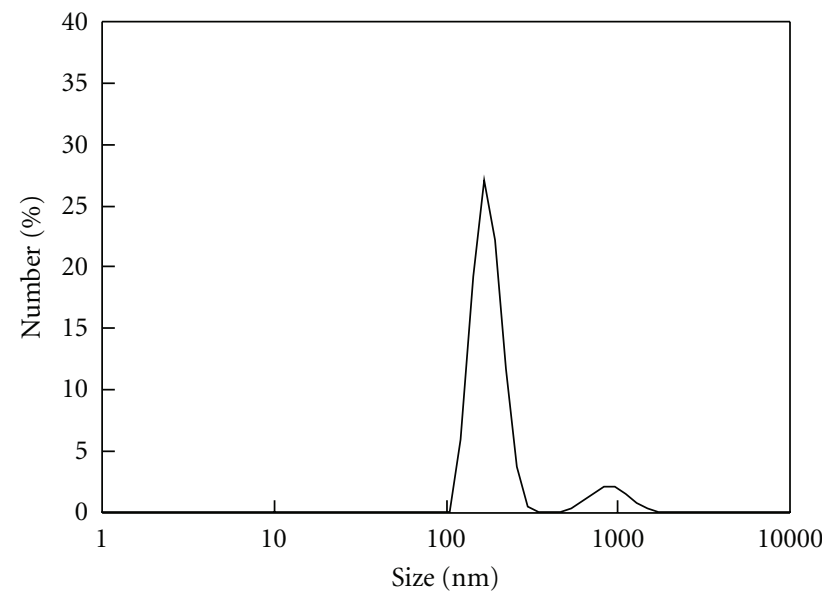

Figure 5: Size distribution profile of the DNA/AET/Au/HA complex encapsulated in calcium phosphate (prepared in SBF with $\mathrm{Ca}=$ $2.6 \mathrm{mM})$.

was measured. In line with the amount of HA, the surface charge of the DNA/AET/Au/HA complex decreased and was saturated at $-35 \mathrm{mV}$ at $\mathrm{HA} / \mathrm{DNA}$ ratio $=23.3$ (in weight). This ratio, where the $\zeta$-potential reaches the lowest level by minimum HA (Figure 2(b)), was employed in the following experiments.

DNA/AET/Au complex coated by HA (DNA : AET : HA = $1: 7.2: 23.3$ in weight) was added to the SBF, and deposition of CaP layer on the surface of DNA/AET/Au/HA complex was attempted. DNA complex suspension was added to 1.5 times concentrated SBF at a final Ca concentration of 1.4, $2.0,2.6$, or $3.1 \mathrm{mM}$. To examine the deposition of $\mathrm{CaP}$, dissociation behavior of the DNA complex in a concentrated $\mathrm{NaCl}$ solution was evaluated. DNA complex immersed in SBF with $1.4 \mathrm{mM}$ Ca ion concentration was dissociated by concentrated $\mathrm{NaCl}$ solution and showed bands at similar positions to those of DNA complex without SBF. On the other hand, the DNA complexes immersed in SBF with more than $2.0 \mathrm{mM}$ Ca did not show bands from dissociated DNA

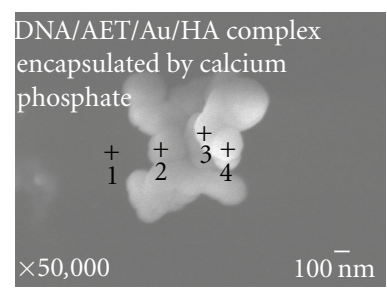

\begin{tabular}{|c|c|c|c|c|c|c|c|c|c|c|c|}
\hline & $\mathrm{C}$ & $\mathrm{O}$ & $\mathrm{Na}$ & $\mathrm{Mg}$ & $\mathrm{P}$ & $\mathrm{S}$ & $\mathrm{Cl}$ & $\mathrm{K}$ & $\mathrm{Ca}$ & $\mathrm{Au}$ & $\begin{array}{c}\text { Total } \\
(\mathrm{mol} \%)\end{array}$ \\
\hline 1 & 88.6 & 11 & 0 & 0.1 & 0 & 0 & 0.3 & 0 & 0 & 0 & 100 \\
\hline 2 & 45.5 & 39.5 & 0.5 & 0 & 7.2 & 0.1 & 2 & 0 & 5.1 & 0.1 & 100 \\
\hline 3 & 41.9 & 33.7 & 8.6 & 0.1 & 4.1 & 0 & 6.6 & 0 & 4.9 & 0 & 100 \\
\hline 4 & 35.5 & 42.9 & 1.9 & 0.1 & 7.8 & 0.9 & 1.7 & 0 & 9.2 & 0 & 100 \\
\hline
\end{tabular}

(b)

(b) DNA/AET/Au/HA complex encapsulated in calcium phosphate

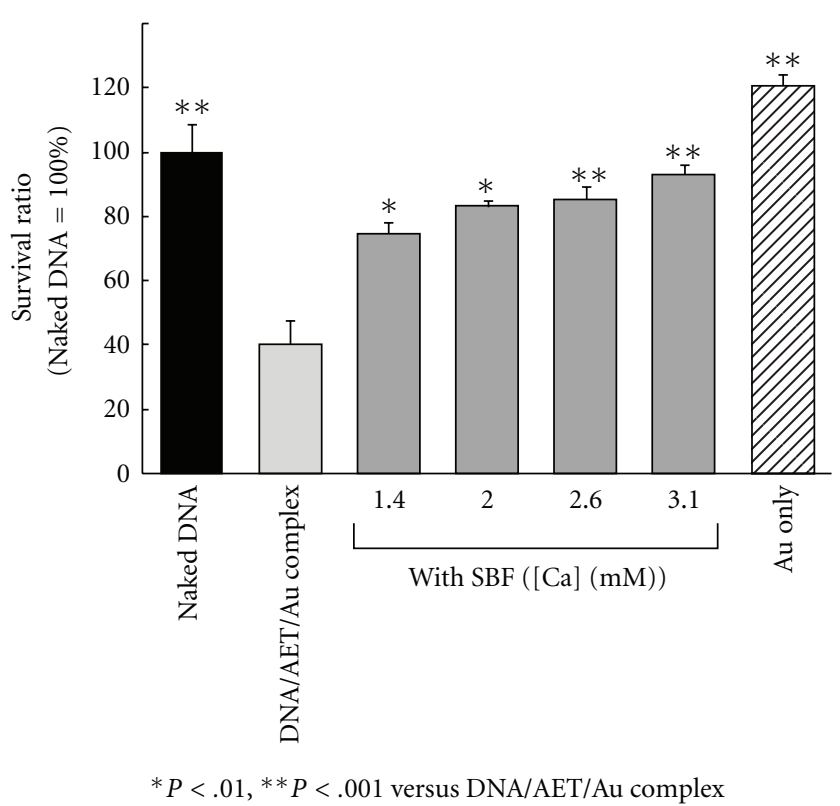

Figure 6: Cytotoxicity of Au nanoparticle and the DNA complexes with or without calcium phosphate envelope.

molecules. This indicates that $\mathrm{CaP}$ could be deposited onto a surface of DNA complex coated by HA by immersion in SBF with more than $2.0 \mathrm{mM} \mathrm{Ca}$ and form a stable encapsulated complex (Figure 3).

Degradation of the CaP capsule in an acidic solution was then examined. An equal volume of $\mathrm{pH} 4.5$ acetate buffer was added to the suspension of DNA/AET/Au/HA complex encapsulated in $\mathrm{CaP}$, which was prepared with $2.6 \mathrm{mM}$ Ca. After stirring at $37^{\circ} \mathrm{C}$ for $24 \mathrm{~h}, 30 \% \mathrm{NaCl}$ solution was added. When it was electrophoresed, a clear band of the dissociated DNA molecule was observed (Figure 3). This shows that the DNA complex was coated with a $\mathrm{CaP}$ layer, which could be dissolved in the acidic conditions, and released the DNA complex encapsulated inside. 


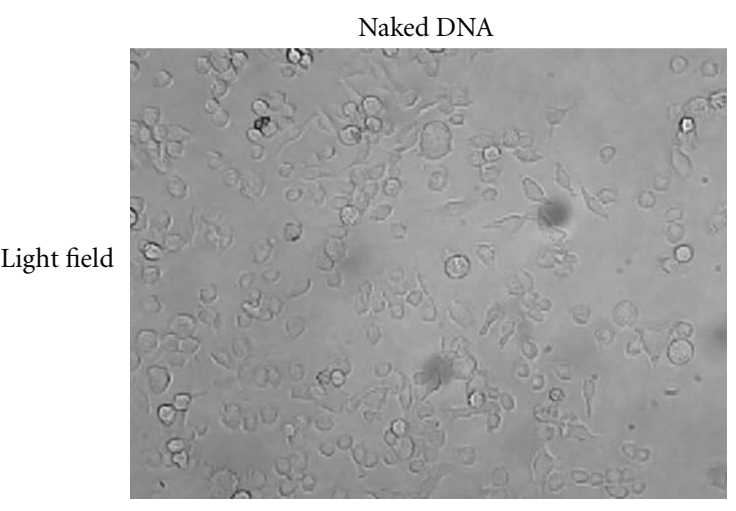

(a)

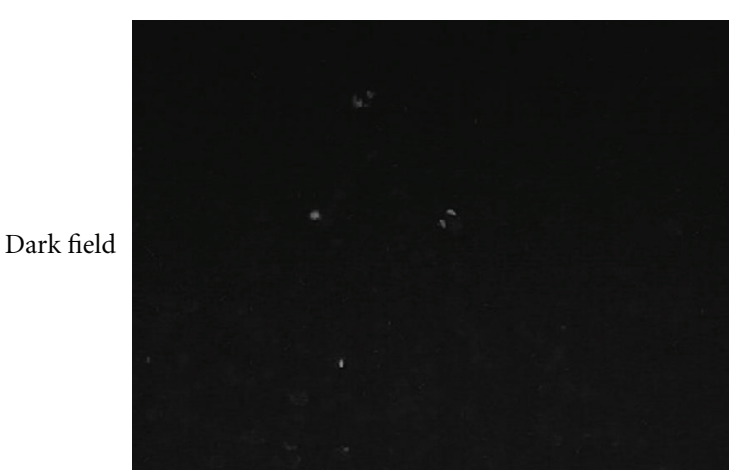

(c)

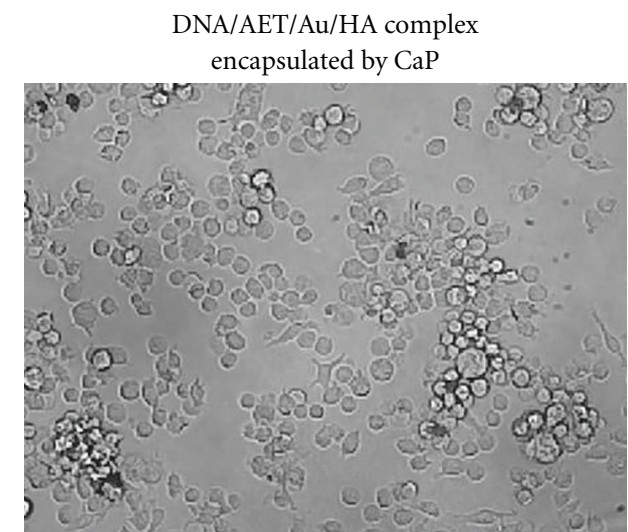

(b)

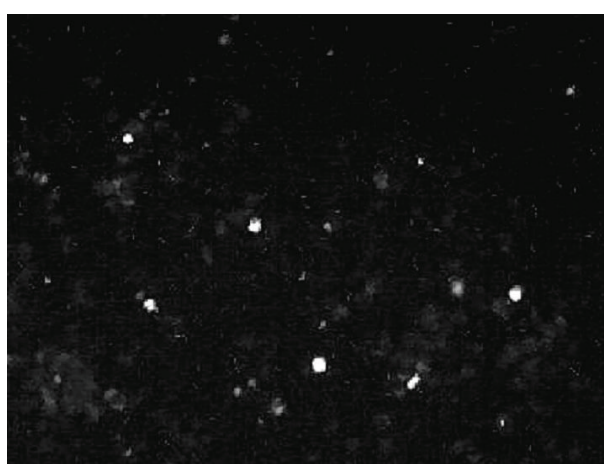

(d)

FIGURE 7: Cellular uptake of fluorescence-labeled naked DNA and its complex with Au encapsulated with CaP.

In SEM-EDS images, differences in surface morphology and composition were observed (Figure 4). Large aggregation of particles with a diameter of ca. $100 \mathrm{~nm}$ was seen in the SEM image of DNA/AET/Au/HA complex, and Au was detected in the particle by EDS analyses (Figure 4(a)). On the other hand, the DNA/AET/Au/HA complex encapsulated in $\mathrm{CaP}$ was an aggregation of particles of $200 \mathrm{~nm}$ in diameter. Calcium and phosphorus were detected in it instead of $\mathrm{Au}$ (Figure 4(b)). It was confirmed that the DNA/AET/Au complex coated with HA could be encapsulated with $\mathrm{CaP}$ by immersion in SBF. The number average size of the DNA/AET/Au/HA complex encapsulated by CaP suspended in water was $175 \mathrm{~nm}$ with the standard deviation of $33.4 \mathrm{~nm}$ (Figure 5). The large aggregation of the encapsulated complex would be formed through the drying procedure for SEM observation.

\subsection{Cytotoxicity of DNA Complex Encapsulated in Calcium} Phosphate. Figure 6 shows the cytotoxicity of the DNA/ $\mathrm{AET} / \mathrm{Au} / \mathrm{HA}$ complex and the encapsulated particles. Judging from the WST-1 assay, DNA/AET/Au complex showed apparent toxicity and only $40 \%$ of the cells survived, while $\mathrm{Au}$ itself showed much less toxicity. This was due to the cationic surface of the DNA/AET/Au complex. On the other hand, DNA complex encapsulated by CaP showed apparently lower toxicity, and more than $80 \%$ of the cells were still alive. Encapsulation by the biocompatible apatite appeared to cause diminished toxicity.

3.3. Cellular Uptake of the Particles. Plasmid DNA was fluorescently labeled by YOYO-1, complexed with gold, and then packaged by CaP. When they were incubated with MLC- 6 cells, the cells became luminescent, while the cells treated with naked DNA/YOYO-1 complex did not show the fluorescence (Figure 7).

3.4. Enzymatic Degradation of DNA Complex Encapsulated in Calcium Phosphate. Enzymatic degradation behavior of the DNA molecule was evaluated by incubation with Hind III followed by agarose gel electrophoresis. DNA molecule in the DNA/AET/Au/HA complex without $\mathrm{CaP}$ was degraded by the enzyme and showed bands of degradation products. A smeared band was observed, unlike for the naked DNA (Figure 8). This was considered to be due to the interaction of the degraded DNA fragments with the cationic polymer. DNA complex not completely encapsulated by $\mathrm{CaP}$, which was prepared in final $[\mathrm{Ca}]=1.4 \mathrm{mM}$, also showed bands of degraded products. On the other hand, DNA complex encapsulated by $\mathrm{CaP}$ at more than final $[\mathrm{Ca}]=2.0 \mathrm{did}$ not show any DNA fragments (Figure 8). Efficient inhibition of 


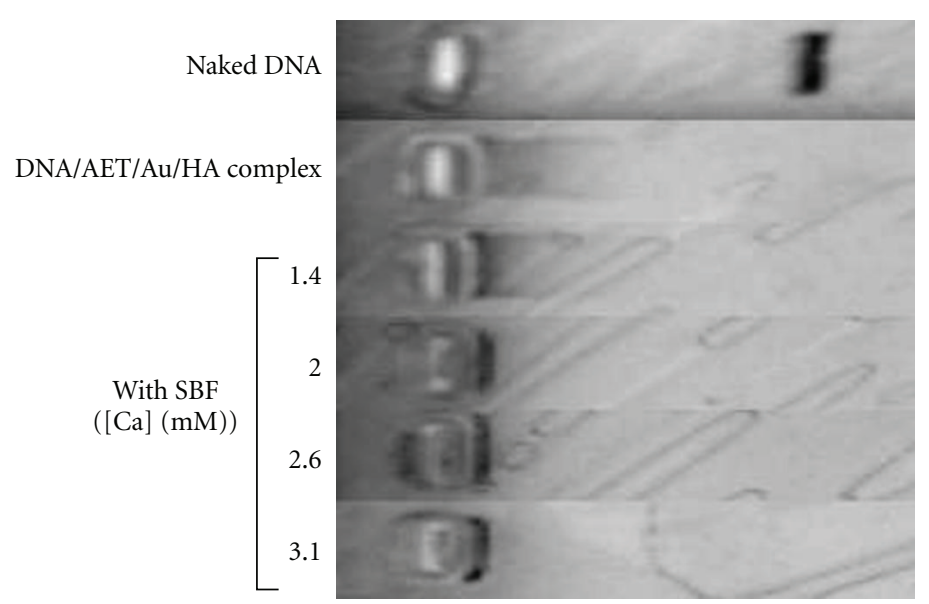

(a)

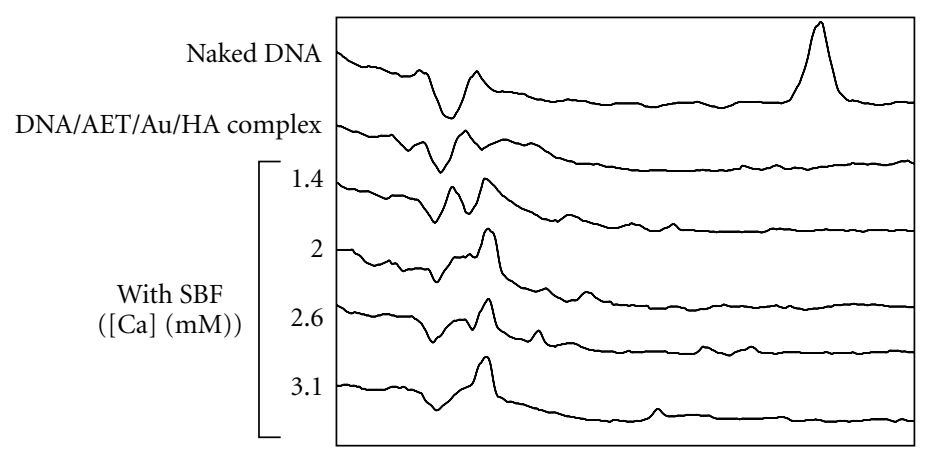

(b)

FIgURE 8: Agarose gel electrophoresis profile of the DNA complex encapsulated in CaP after degradation by Hind III.

DNA degradation by an enzyme by encapsulation with Cap was confirmed.

CaP-encapsulated DNA/gold nanoparticle has high biocompatibility and resistance against enzymatic degradation and also the releasing property by cellular degradation. It is expected to be a safe and durable nonviral system for gene therapy.

\section{Conclusion}

DNA/gold complex was efficiently included in a CaP capsule by coating the complex with hyaluronic acid followed by immersion in SBF with a Ca concentration above $2 \mathrm{mM}$. Biocompatibility and resistance against enzymatic degradation were apparently enhanced by the encapsulation with $\mathrm{CaP}$. Incubation of the CaP capsule including DNA complex in an acidic acetate buffer invited the release of DNA complex from the capsule. This shows the high potential of the CaP capsule as an injectable slow-release device, which would release the contained DNA complex by degradation by osteoclasts.

\section{Acknowledgments}

The authors thank Professor K. Yoshikawa (Kyoto University) for his help with the $\zeta$-potential and size measurements. This work was partly supported by the Japan Society for the Promotion of Science (no. 21700494), Foundation for
Promotion of Material Science and Technology of Japan, and MEXT HAITEKU (2008) from the Ministry of Education.

\section{References}

[1] X. Zhou and L. Huang, "DNA transfection mediated by cationic liposomes containing lipopolylysine: characterization and mechanism of action," Biochimica et Biophysica Acta, vol. 1189, no. 2, pp. 195-203, 1994.

[2] K. Taira, K. Kataoka, and T. Niidome, Eds., Non-Viral Gene Therapy: Gene Design and Delivery, Springer, Tokyo, Japan, 2005.

[3] S. M. Mel'nikov, V. G. Sergeyev, and K. Yoshikawa, "Discrete coil-globule transition of large DNA induced by cationic surfactant," Journal of the American Chemical Society, vol. 117, no. 9, pp. 2401-2408, 1995.

[4] C. Plank, K. Mechtler, F. C. Szoka Jr., and E. Wagner, "Activation of the complement system by synthetic DNA complexes: a potential barrier for intravenous gene delivery," Human Gene Therapy, vol. 7, no. 12, pp. 1437-1446, 1996.

[5] Y. Koyama, T. Ito, H. Matsumoto et al., "Novel poly(ethylene glycol) derivatives with carboxylic acid pendant groups: synthesis and their protection and enhancing effect on non-viral gene transfection systems," Journal of Biomaterials Science, Polymer Edition, vol. 14, no. 6, pp. 515-531, 2003.

[6] T. Ito, N. Iida-Tanaka, and Y. Koyama, "Efficient in vivo gene transfection by stable DNA/PEI complexes coated by 
hyaluronic acid," Journal of Drug Targeting, vol. 16, no. 4, pp. 276-281, 2008.

[7] D. Olton, J. Li, M. E. Wilson et al., "Nanostructured calcium phosphates (NanoCaPs) for non-viral gene delivery: influence of the synthesis parameters on transfection efficiency," Biomaterials, vol. 28, no. 6, pp. 1267-1279, 2007.

[8] C. Kneuer, M. Sameti, E. G. Haltner et al., "Silica nanoparticles modified with aminosilanes as carriers for plasmid DNA," International Journal of Pharmaceutics, vol. 196, no. 2, pp. 257$261,2000$.

[9] T. Niidome, M. Yamagata, Y. Okamoto et al., "PEG-modified gold nanorods with a stealth character for in vivo applications," Journal of Controlled Release, vol. 114, no. 3, pp. 343347, 2006.

[10] P. Ghosh, G. Han, M. De, C. K. Kim, and V. M. Rotello, "Gold nanoparticles in delivery applications," Advanced Drug Delivery Reviews, vol. 60, no. 11, pp. 1307-1315, 2008.

[11] G. Schmid, "Large clusters and colloids. Metals in the embryonic state," Chemical Reviews, vol. 92, no. 8, pp. 17091727, 1992.

[12] X. Huang, I. H. El-Sayed, W. Qian, and M. A. El-Sayed, "Cancer cell imaging and photothermal therapy in the nearinfrared region by using gold nanorods," Journal of the American Chemical Society, vol. 128, no. 6, pp. 2115-2120, 2006.

[13] I. H. El-Sayed, X. Huang, and M. A. El-Sayed, "Surface plasmon resonance scattering and absorption of anti-EGFR antibody conjugated gold nanoparticles in cancer diagnostics: applications in oral cancer," Nano Letters, vol. 5, no. 5, pp. 829834, 2005.

[14] T. Kawano, M. Yamagata, H. Takahashi et al., "Stabilizing of plasmid DNA in vivo by PEG-modified cationic gold nanoparticles and the gene expression assisted with electrical pulses," Journal of Controlled Release, vol. 111, no. 3, pp. 382389, 2006.

[15] S. V. Dorozhkin and M. Epple, "Biological and medical significance of calcium phosphates," Angewandte ChemieInternational Edition, vol. 41, no. 17, pp. 3130-3146, 2002.

[16] S. A. Redey, S. Razzouk, C. Rey et al., "Osteoclast adhesion and activity on synthetic hydroxyapatite, carbonated hydroxyapatite, and natural calcium carbonate: relationship to surface energies," Journal of Biomedical Materials Research, vol. 45, no. 2, pp. 140-147, 1999.

[17] M. P. Ginebra, T. Traykova, and J. A. Planell, "Calcium phosphate cements as bone drug delivery systems: a review," Journal of Controlled Release, vol. 113, no. 2, pp. 102-110, 2006.

[18] T. Kokubo and H. Takadama, "How useful is SBF in predicting in vivo bone bioactivity?" Biomaterials, vol. 27, no. 15, pp. 2907-2915, 2006.

[19] M. Tanahashi and T. Matsuda, "Surface functional group dependence on apatite formation on self- assembled monolayers in a simulated body fluid," Journal of Biomedical Materials Research, vol. 34, no. 3, pp. 305-315, 1997. 

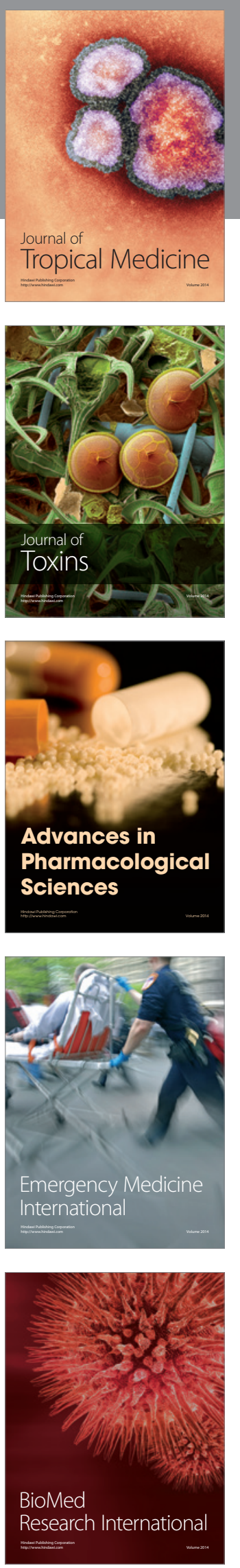
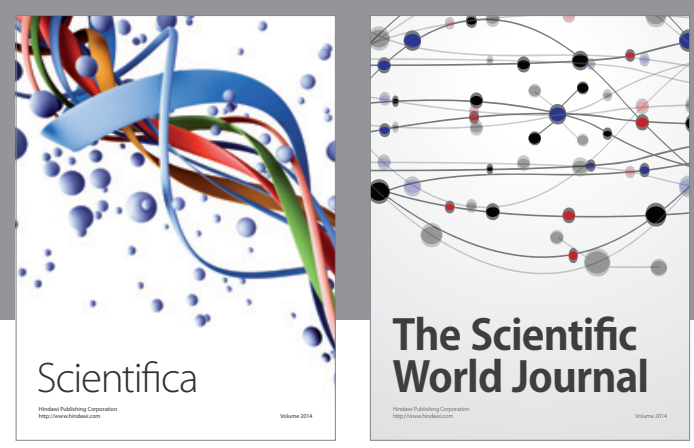

The Scientific World Journal
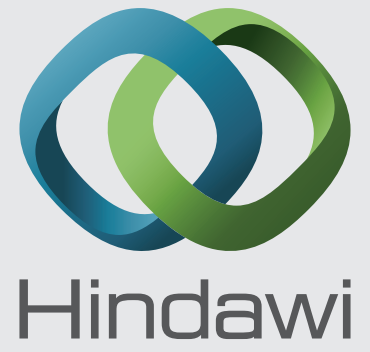

Submit your manuscripts at

http://www.hindawi.com
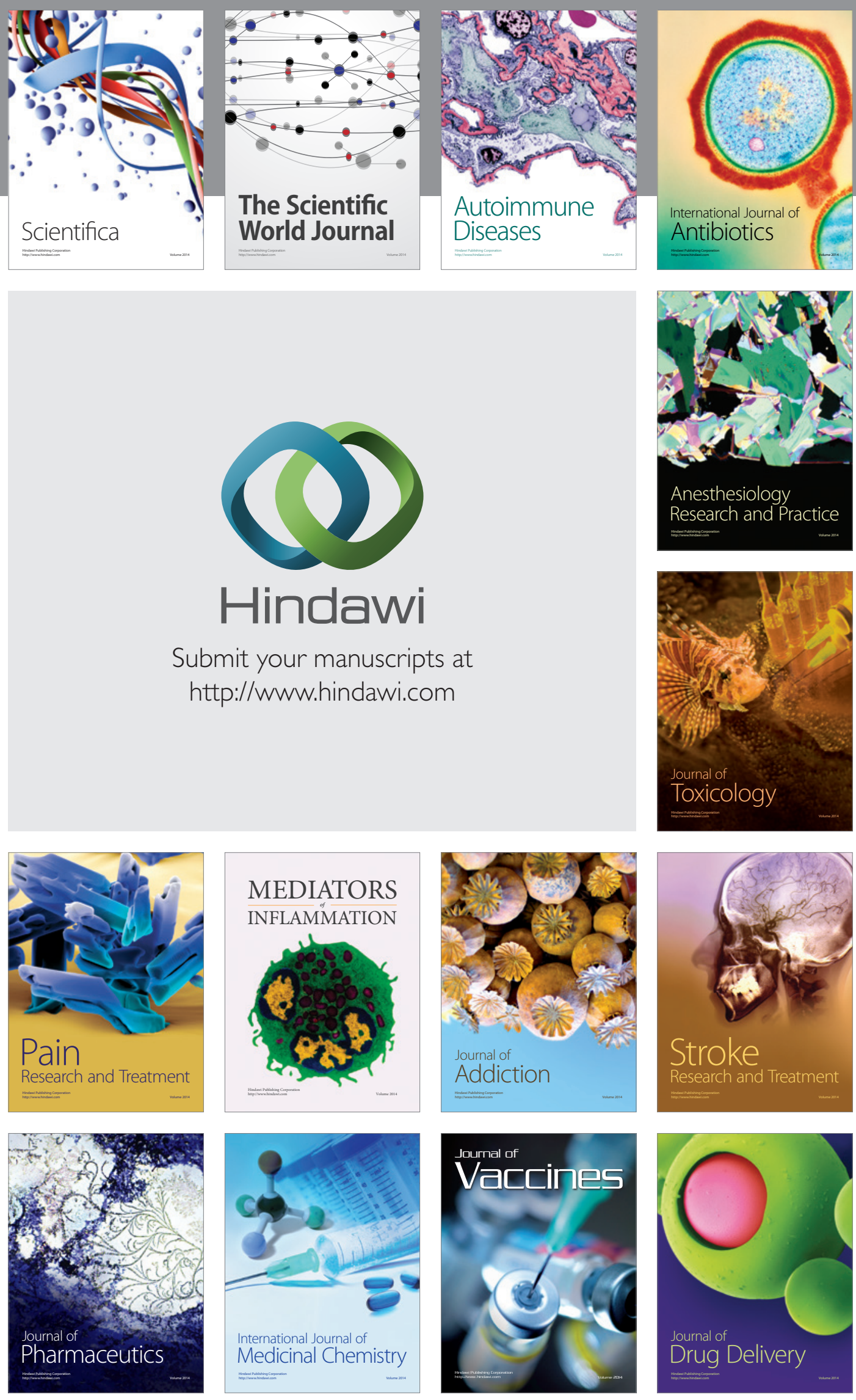